\title{
Electrophysiology of Morphologically Identified Mossy Cells of the Dentate Hilus Recorded in Guinea Pig Hippocampal Slices
}

\author{
H. E. Scharfman ${ }^{1}$ and P. A. Schwartzkroin ${ }^{1,2}$ \\ Departments of ${ }^{~}$ Neurological Surgery and ${ }^{2}$ Physiology and Biophysics, University of Washington, Seattle, Washington \\ 98195
}

A specific population of cells located in the hilus of the hippocampal fascia dentata was studied in guinea pig hippocampal slices using standard intracellular recording techniques. Twenty-one such cells were characterized using electrophysiological techniques and were identified morphologically as mossy cells following intracellular injection of the fluorescent dye Lucifer yellow. These cells had a resting membrane potential (mean, $-64.6 \mathrm{mV}$ ), action potential amplitude (mean, $78.6 \mathrm{mV}$ ), action potential duration (mean, $2.2 \mathrm{msec}$ ), and time constant (mean, $24.2 \mathrm{msec}$ ) similar to those of hippocampal pyramidal cells of area CA3. Rectification seen in their $\mathrm{I}-\mathrm{V}$ curves, and their ability to fire action potentials in accommodating trains or bursts in response to injected current pulses, were also similar to those of area CA3 pyramidal cells. However, these cells could be distinguished from area CA3 pyramidal cells by their higher input resistance (mean, 97.4 $\mathrm{M} \Omega$ ) and higher level of spontaneous activity.

The synaptic responses of mossy cells were also different from those of CA3 pyramidal cells. First, mossy cells responded to low levels of stimulation in all areas of the hippocampal slice that were tested, even areas as remote as area CA1. Second, the responses of mossy cells to stimulation conslsted primarlly of EPSPS. Hyperpolarizing IPSPlike events followed EPSPs in some cells, but the hyperpolarizations were small and monophasic, even after the cell was depolarized with current injection. This response contrasts with the smaller EPSP and the prominent, biphasic IPSP elicited by afferent stimulation of area CA3 pyramidal cells.

The physiological and morphological characteristics of these cells suggest that they could play an important role in the integration of electrical activity in the hippocampus.

The physiology of the principal cells of the hippocampus has been thoroughly studied (see Schwartzkroin and Mueller, 1987, for review). The trisynaptic circuit, connecting dentate granule cells with pyramidal cells of areas CA 3 and CA1, is well established, as are the other afferents and efferents of these cells

\footnotetext{
Received Sept. 28, 1987; revised Feb. 24, 1988; accepted Mar. 1, 1988.

We would like to thank D. Kunkel and M. Gross for their assistance with anatomical techniques. This work was supported by NINCDS Grants NS-18895, NS-15317, and NS-07144.

Correspondence should be addressed to Dr. H. E. Scharfman, Department of Neurological Surgery, RI-20, University of Washington, Seattle, WA 98195.

Copyright (C) 1988 Society for Neuroscience $0270-6474 / 88 / 103812-10 \$ 02.00 / 0$
}

(Ramón y Cajal, 1911; Lorente de No, 1934; Andersen, 1975). However, detailed physiological studies of hippocampal interneurons and their synaptic connections are relatively rare (Schwartzkroin and Mathers, 1978; Knowles and Schwartzkroin, 1981; Misgeld and Frotscher, 1986; Lacaille et al., 1987) despite morphological indications of rich and varied local circuitry (Ramón y Cajal, 1911; Lorente de No, 1934; Blackstad, 1963; Amaral, 1978).

One area for which such physiological information is clearly lacking is the hilus of the fascia dentata. Morphological reports differ in their interpretations of the organization, cell types, and boundaries of the region (Ramón y Cajal, 1911; Lorente de No, 1934; Blackstad, 1963; Amaral, 1978), but all agree on the potential importance of this region in regulating hippocampal input and output. Dentate granule cell axons, or "mossy fibers," project to the CA3 region, and their collaterals project heavily to hilar neurons (Claiborne et al., 1986). Some hilar neurons, such as the "mossy cells," are almost covered with highly specialized regions of synaptic contact-called "thorny excrescences" - for mossy fiber terminals (Amaral, 1978). The hilus is also the target of many afferent inputs, such as noradrenergic fibers from the locus coeruleus, serotonergic fibers from the raphe, and cholinergic input from the septum (Storm-Mathisen and Blackstad, 1964; Conrad et al., 1974; Moore and Halaris, 1975; Swanson and Hartman, 1975). Some hilar cells are likely to be local circuit neurons, with an axon that arborizes locally (Amaral, 1978); others, such as the mossy cell, project to the ipsilateral and contralateral dentate gyrus (Gottlieb and Cowan, 1973; Swanson et al., 1978, 1981; Laurberg and Sorensen, 1981; Ribak et al., 1985). That hilar cells, and in particular mossy cells, could play an important role in hippocampal physiology has been suggested by recent studies showing a destruction of mossy cells during the development of seizure activity in the dentate gyrus (Sloviter, 1987).

Mossy cells have been described in detail on the basis of Golgi studies of the rat hilar region (Amaral, 1978; Ribak et al., 1985). These cells are the most numerous cell type in the hilus. The cell body is multipolar, with 3-4 primary dendrites. The somata and proximal dendrites are covered by thorny excrescences, while the distal dendrites have more conventional spines. The extremely large dendritic tree covers the hilus, extending up to the edges of the granule cell layer, but rarely passing into it. Dendrites branch in a characteristic pattern, with long segments between branches and branching that occurs at acute angles, rather than dendrites that form tufts. Spines have been observed on the initial segment of the axon. 
Although the morphological portrait of mossy cells is detailed, little is known concerning the physiology of mossy cells. Here we report the results of intracellular electrophysiological studies of mossy cells that were morphologically identified following intracellular injection of the fluorescent dye Lucifer yellow. The fundamental intrinsic properties and synaptic responses of these cells are described.

\section{Materials and Methods}

\section{Morphology}

Location and morphology of mossy cells. Perfusions for all morphological studies were performed under deep anesthesia after intraperitoneal injection of sodium pentobarbital $(>50 \mathrm{mg} / \mathrm{kg}$ ).

For Nissl staining, male Hartley guinea pigs (200-300 gm) were perfused (200-300 ml phosphate-buffered formalin), the hippocampus dissected from the brain and left in fixative overnight. After $24 \mathrm{hr}$ in $30 \%$ sucrose, the tissue was sectioned ( $25 \mu \mathrm{m}$ transverse sections) on a freezing-stage microtome, and stained with cresyl violet (Sheehan and Hrapchak, 1980).

To stain mossy fiber terminals, the hippocampus was stained according to Timm's method, as outlined by Haug (1973). The brain was perfused with $200-300 \mathrm{ml}$ of the following solution: $11.7 \mathrm{gm} \mathrm{Na}_{2} \mathrm{~S}, 11.9$ gm $\mathrm{NaH}_{2} \mathrm{PO}_{4}$, and $1000 \mathrm{ml} d-\mathrm{H}_{2} \mathrm{O}$. The hippocampus was dissected from one hemisphere; both the dissected hippocampus and the intact hemisphere were left in dry ice overnight. Sagittal sections $(20 \mu \mathrm{m})$ of the intact hemisphere were cut on a cryostat; the dissected hippocampus was sectioned parallel to the lamellae (i.e., transverse to its long axis). Sections were stained in the dark [staining solution: $360 \mathrm{ml}$ gum arabic $\left(500 \mathrm{gm} / 1 d-\mathrm{H}_{2} \mathrm{O}\right), 60 \mathrm{ml}$ citrate buffer, $180 \mathrm{ml}$ hydroquinone $(5.67 \mathrm{gm} /$ $100 \mathrm{ml} d-\mathrm{H}_{2} \mathrm{O}$; Kodak), and $3 \mathrm{ml} \mathrm{AgNO} 3\left(1.7 \mathrm{gm} / 10 \mathrm{ml} d-\mathrm{H}_{2} \mathrm{O}\right.$; Alfa Products)] rinsed, dehydrated, and coverslipped with Canada balsam.

A modification of the rapid Golgi method was used to examine mossy cell morphology (Millhouse, 1981). Animals were perfused as for Nissl staining, the hippocampus dissected out and left in fixative overnight. The hippocampus was then rinsed in $d-\mathrm{II}_{2} \mathrm{O}$ and cut transversely into 3-4-mm-thick blocks. All blocks from each hippocampus were placed in approximately $50 \mathrm{ml}$ of the following solution: $12 \mathrm{gm} \mathrm{K}_{2} \mathrm{Cr}_{2} \mathrm{O}_{7}, 1 \mathrm{gm}$ $\mathrm{OsO}_{4}$, and $500 \mathrm{ml} d-\mathrm{H}_{2} \mathrm{O}$, and left for $5 \mathrm{~d}$ in the dark. Blocks were rinsed in $d-\mathrm{H}_{2} \mathrm{O}(1 \mathrm{~min}), 0.25 \% \mathrm{AgNO}_{3}(2 \mathrm{~min}), 0.5 \% \mathrm{AgNO}_{3}(2 \mathrm{~min})$, and $0.75 \% \mathrm{AgNO}_{3}$ (3 rinses, 2 min each), then left in fresh $0.75 \% \mathrm{AgNO}_{3}$ ( $10 \mathrm{ml}$ solution/hippocampus) for $7 \mathrm{~d}$ in the dark. Blocks were embedded in $12 \%$ celloidin, and $75 \mu \mathrm{m}$ sections were cut on a sliding microtome. Sections were first rinsed in a solution of $300 \mathrm{ml}$ of $100 \%$ alcohol and $100 \mathrm{ml}$ chloroform ( 2 rinses, $3 \mathrm{~min}$ each), and then in $50 \mathrm{ml}$ methyl benzoate, $200 \mathrm{ml}$ benzyl alcohol, and $150 \mathrm{ml}$ chloroform $(3 \mathrm{~min}$ ). Sections were mounted on subbed slides, left to dry (5-10 min), soaked in toluene overnight, and coverslipped with Micromount (American Histological Reagent Co.). Nissl, Timm's, or Golgi material was photographed on a Leitz Dialux 20 microscope with 32 ASA black and white print film (Pan-X; Kodak).

The following criteria were used to morphologically classify a hilar cell as a mossy cell: (1) the cell body was located greater than $100 \mu \mathrm{m}$ from the granule cell layer and greater than $200 \mu \mathrm{m}$ from the layer of pyramidal cells in the center of the hilus (layer 2 of Fig. 1); (2) there were 3-4 thick primary dendrites with numerous thorny excrescences, and conventional spines on distal dendrites; (3) dendrites with long segments between branches and with branches that made acute angles with the parent dendrite were present; and (4) there was an extensive, nonpolar dendritic tree confined to the hilus, with dendrites that stopped or bent at the granule cell layer. Occasionally, a single dendrite passed into the molecular layer.

Intracellular staining with Lucifer yellow. Electrodes were filled with $3 \%$ Lucifer yellow $\mathrm{CH}$ dissolved in $1 \mathrm{M} \mathrm{LiCl}$ or $1 \mathrm{M} \mathrm{Li}_{2} \mathrm{SO}_{4}$. Tonic hyperpolarizing current (typically $1.0 \mathrm{nA}$ for $15 \mathrm{~min}$; range, -0.5 to $-1.5 \mathrm{nA} ; 5-25 \mathrm{~min}$ ) was used to eject Lucifer yellow during intracellular recording. After the cell was injected with dye, the slice was placed between 2 pieces of filter paper that were soaked with $10 \%$ buffered neutral formalin. The next day the slice was dehydrated and placed on a subbed slide. A few drops of methyl salicylate were placed on the slice until it was transparent; then it was coverslipped with methyl salicylate. Cells were examined with a Leitz Dialux 20 epifluorescence microscope using a H-2 filter cube (excitation wavelengths, 390-490 nm), and photographed with 400 ASA black and white print film (Tri-X; Kodak).

\section{Electrophysiology}

Preparation of hippocampal slices. Male Hartley guinea pigs (175-400 $\mathrm{gm}$ ) were decapitated with a small animal guillotine and the brain quickly removed. The hippocampus was dissected while keeping the tissue chilled with oxygenated buffer, and sliced ( $450 \mu \mathrm{m}$ thick) at an orientation parallel to the lamellae, using a McIlwain tissue chopper (Brinkmann). Slices were immediately placed in an interface recording chamber (Schwartzkroin, 1975), where they were warmed $\left(35^{\circ} \mathrm{C}\right.$ ), oxygenated $\left(95 \% \mathrm{O}_{2}, 5 \% \mathrm{CO}_{2}\right)$, and perfused $(1 \mathrm{ml} / \mathrm{min})$ with modified Krebs-Ringer buffer (in mM: $126 \mathrm{NaCl}, 5 \mathrm{KCl}, 2 \mathrm{CaCl}_{2}, 2 \mathrm{MgSO}_{4}, 1.25 \mathrm{NaH}_{2} \mathrm{PO}_{4}, 26$ $\mathrm{NaHCO}_{3}$, and 10 dextrose; $\mathrm{pH} 7.4$ ).

Intracellular recording. Neurons were accepted for physiological study if (1) their resting membrane potentials (RMPs) were over $-50 \mathrm{mV}$, (2) action potentials (APs) were overshooting, (3) the time constant exceeded $5 \mathrm{msec}$, and (4) input resistance $\left(R_{\mathrm{in}}\right)$ was greater than $25 \mathrm{M} \Omega$.

Intracellular recording electrodes were pulled from borosilicate glass containing a capillary fiber in the lumen (50-150 M $\Omega$ ). Electrodes were filled with $3 \%$ Lucifer yellow $\mathrm{CH}$ dissolved in $1 \mathrm{M} \mathrm{LiCl}$ or $1 \mathrm{M} \mathrm{Li}_{2} \mathrm{SO}_{4}$. Bipolar stimulating electrodes were made from resin-coated, electrolytically etched tungsten microelectrodes spaced $100 \mu \mathrm{m}$ apart at the tips. The tips of the stimulating electrode were placed on the slice surface more than $500 \mu \mathrm{m}$ from the cell, and stimuli (square pulses, 5-500 $\mu \mathrm{A}$, 20-200 $\mu \mathrm{sec}$ ) of increasing amplitude were applied until a response was elicited. Thereafter stimulus intensity was further increased to examine (1) changes in the subthreshold response with increased stimulus intensity, (2) threshold responses, and (3) suprathreshold (up to 3 times threshold stimulus strength) responses. Stimulus frequency never exceeded $0.33 \mathrm{~Hz}$.

An amplifier with a bridge circuit (model IR-283; Neurodata) was used for intracellular recording. Data were recorded on tape with a digitizing tape recorder system (Neurocorder model DR-484; Neurodata) and analyzed by computer (Norland 3001/DMX).

Data analysis. Analysis of APs was done from APs evoked by a threshold depolarizing current pulse. Spontaneous APs were not used for measurements because some cells did not fire spontaneously. AP amplitude was measured from the RMP to the peak of the AP. Total $\mathrm{AP}$ duration was measured where the AP intersected the ohmic portion of the response to the current pulse. AP half-width was measured from the start of the AP at its base to the point on the rising phase of the AP that was half its amplitude. Action potential afterhyperpolarization (AHP) amplitude following a single AP was measured for those cells in which a spike afterpotential dipped below RMP, and was determined from RMP to the peak of the hyperpolarization. The duration of the AHP following a single AP was measured from the point at which the repolarizing phase of the AP intersected the RMP to the point at which cell membrane potential returned to RMP. The amplitude of the postburst AHP (the AHP following a train of current-elicited APs) was measured from the RMP to the peak of the hyperpolarization. The duration of the postburst AHP was measured from the end of the 100 msec pulse used to depolarize the cell to the point at which the membrane potential returned to RMP. Cell time constant was calculated as the time required for membrane potential to reach $63 \%$ of the steadystate amplitude in response to a $-0.2 \mathrm{nA}, 100 \mathrm{msec}$ current pulse. $R_{\text {in }}$ was determined from the slope of the linear portion of the I-V curve, where I was the amplitude of the rectangular current pulse (0.1-1.0 nA, $100 \mathrm{msec}$ ), and $\mathrm{V}$ was the steady state voltage response measured at the end of the pulse. In analyzing synaptic responses to slice stimulation, latency was determined as time from the end of the stimulus artifact to the onset of the postsynaptic potential (PSP) elicited near threshold; PSP onset was sharp enough to distinguish easily from noise. PSP amplitude was measured from RMP to peak.

\section{Results}

\section{Location and morphological identification of mossy cells}

Nissl- and Timm's-stained sections provided a detailed view of the organization of cell layers of the dentate gyrus and underlying hilar region in the guinea pig (Fig. 1).

There were 3 layers in the hilus, and these were similar to those that have been described previously for the guinea pig by Blackstad (1963): (1) a narrow, relatively acellular layer located just beneath the granule cell layer (limiting subzone of Cajal, $S$ zone of Blackstad), (2) another narrow band situated underneath 

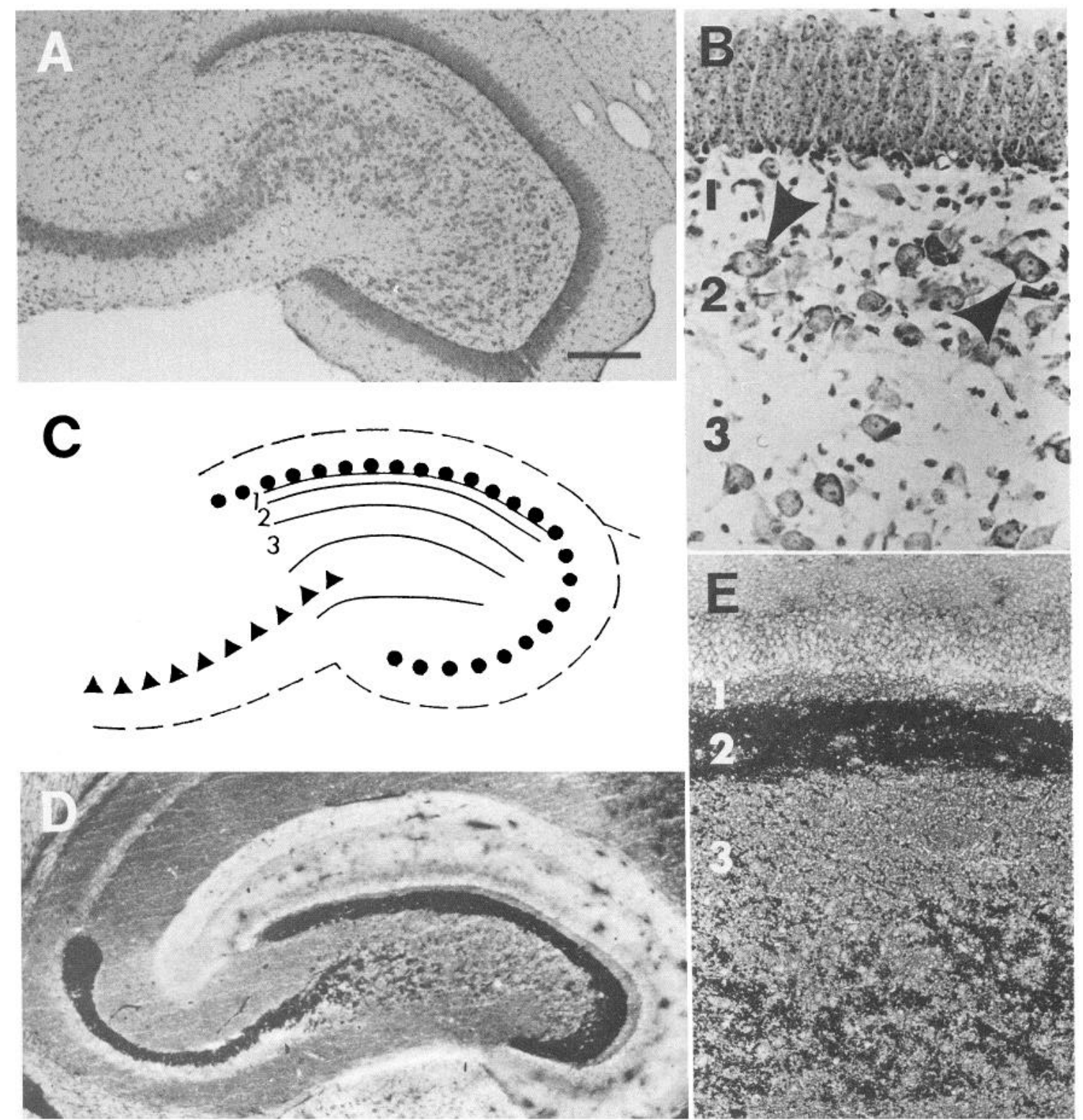

Figure 1. Cell layers of the dentate hilus. A, Nissl-stained transverse section of the dentate gyrus. Area CA3 of the hippocampus is to the left. Calibration, $200 \mu \mathrm{m}$. B. Higher magnification of the hilus of the section shown in A. Layers $1-3$ are indicated on the left. Arrowheads point to large cells in layer 2. Calibration (in part $A$ ), $50 \mu \mathrm{m}$. C, Diagram of the dentate gyrus outlining the 3 layers of the hilus (see text). The row of circles represents the dentate granule cell layer; the row of triangles represents the pyramidal cell layer extending from area CA3. $D$, Low-power photograph of a Timm's-stained sagittal section of the dorsal hippocampus. Darker areas represent regions where the concentration of heavy metals was high. Calibration (in part $A$ ), $275 \mu \mathrm{m}$. E , Higher-power photograph of the hilus in $D$. The layers of the hilus are indicated on the left. Calibration (in part $A), 75 \mu \mathrm{m}$.

the first that contained larger cells (plexiform subzone of Cajal, $\mathrm{Z}$ zone of Blackstad), and (3) a mixed layer below layer 2 containing both large and small cells (subzone of fusiform cells of Cajal, $\mathrm{H}$ zone of Blackstad).

A population of very large multipolar cells was evident in layer 2 (Fig. 1B). Many of these cells were likely to be mossy cells, since mossy cells have large, multipolar cell bodies and are the predominant cell type in the hilus (Amaral, 1978). Timm's-stained sections also indicated that these cells might be mossy cells, since layer 2 stained heavily for the zinc-laden mossy fiber collateral terminals that oppose mossy cell thorny excrescences (Fig. 1, D,E). This pattern of staining was the same in sections from a hemisphere that was sectioned sagittally and in sections from a hippocampus that was sectioned parallel to the lamellae. Others have also found that layer 2 in the guinea pig stains intensely using Timm's method; in fact, Blackstad (1963) labeled the layer the " $Z$ zone" because of the prominent staining of the heavy metal zinc.

Mossy cells that were stained by the rapid Golgi method (Millhouse, 1981) were located in layer 2. Figure $2 A$ illustrates a typical Golgi-impregnated mossy cell from the adult guinea pig, located in layer 2 of the hilus. Three large primary dendrites had numerous thorny excrescences proximally and dendritic spines distally. Long dendrites could be followed to the granule cell layer, where they stopped or bent away from the granule cells. These features of guinea pig cells have been reported as characterizing rat mossy cells (see the introduction; Amaral, 1978; Ribak et al., 1985). 


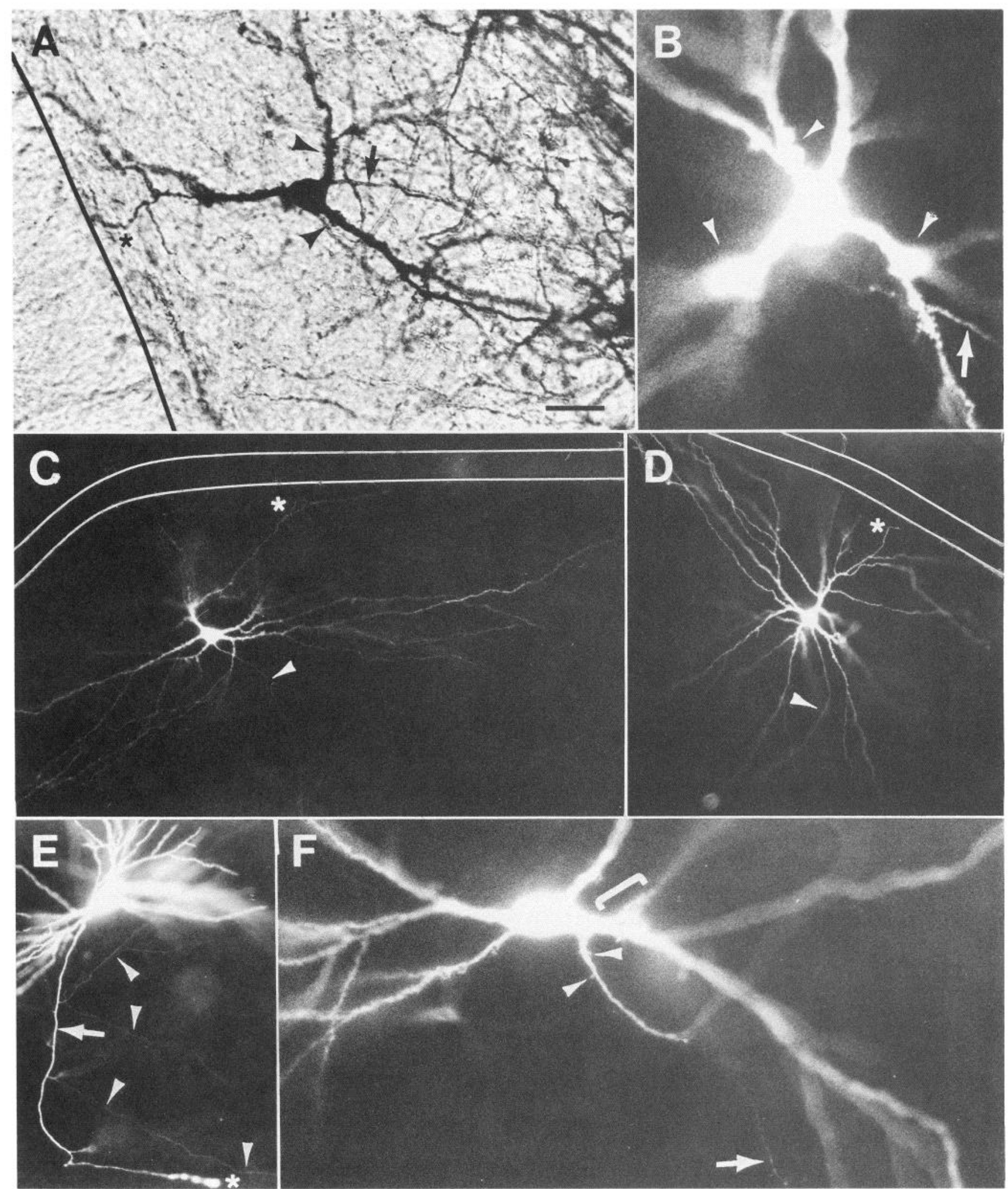

Figure 2. Morphology of mossy cells. A, A mossy cell stained by the rapid Golgi method. The lower border of the upper blade of the granule cell layer is marked by a dark line. An asterisk indicates a portion of dendrite that bends away from the granule cell layer. Arrowheads point to thorny excrescences. The arrow marks the axon. Calibration, $50 \mu \mathrm{m}$. B. Thorny excrescences (arrowheads) of a Lucifer yellow-filled mossy cell. The arrow indicates the axon. For $B, E$, and $F$, the upper blade of the dentate gyrus is above the photos. Calibration (shown in part $A$ ), $20 \mu \mathrm{m}$. $C, D$, Two different mossy cells illustrating the large dendritic tree that spans the hilus. The borders of the granule cell layer (upper blade) are marked by white lines. Arrowheads mark the axons. Asterisks indicate dendrites that bend near the granule cell layer. Calibration (in $A$ ), $100 \mu \mathrm{m}$. $E$, Typical axonal branching pattern of a mossy cell. The axon (arrow) descends into the central hilus and sends collaterals (arrowheads) into the hilus and towards the granule cell layer. The asterisk marks swellings at the end of the axon, which may indicate the cut end of the axon at the slice surface. Calibration (in $A$ ), $75 \mu \mathrm{m}$. F. Spines (arrowheads) on the initial segment of a mossy cell. The bracket encloses a thorny excrescence. The arrow marks the axon. Calibration (in $A$ ), $25 \mu \mathrm{m}$. 
Figure 3. Responses of mossy cells to hyperpolarizing current pulses. $A$, Responses to $0.1,0.2,0.3$, and $0.6 \mathrm{n} \Lambda$, 100 msec duration hyperpolarizing current pulses. A photograph of this cell is shown in Figure $2 B$. RMP, $-60 \mathrm{mV}$. $B$, I-V curve of the cell shown in Figure $2 B$. C, I-V curve based on data from all mossy cells. Mean values \pm SEM are plotted. The number of cells tested for a given amplitude pulse is shown above each point. $D$, Responses to a 0.2 $\mathrm{nA}, 100$ msec hyperpolarizing current pulse at 3 different membrane potentials. The smallest response was recorded at $-72 \mathrm{mV}$; the intermediate responsc at RMP $(-60 \mathrm{mV})$; and the largest at $-53 \mathrm{mV}$. Same calibration as in $A$. The morphology of this cell is shown in Figure $2 D$. Capacitance artifacts are clipped.

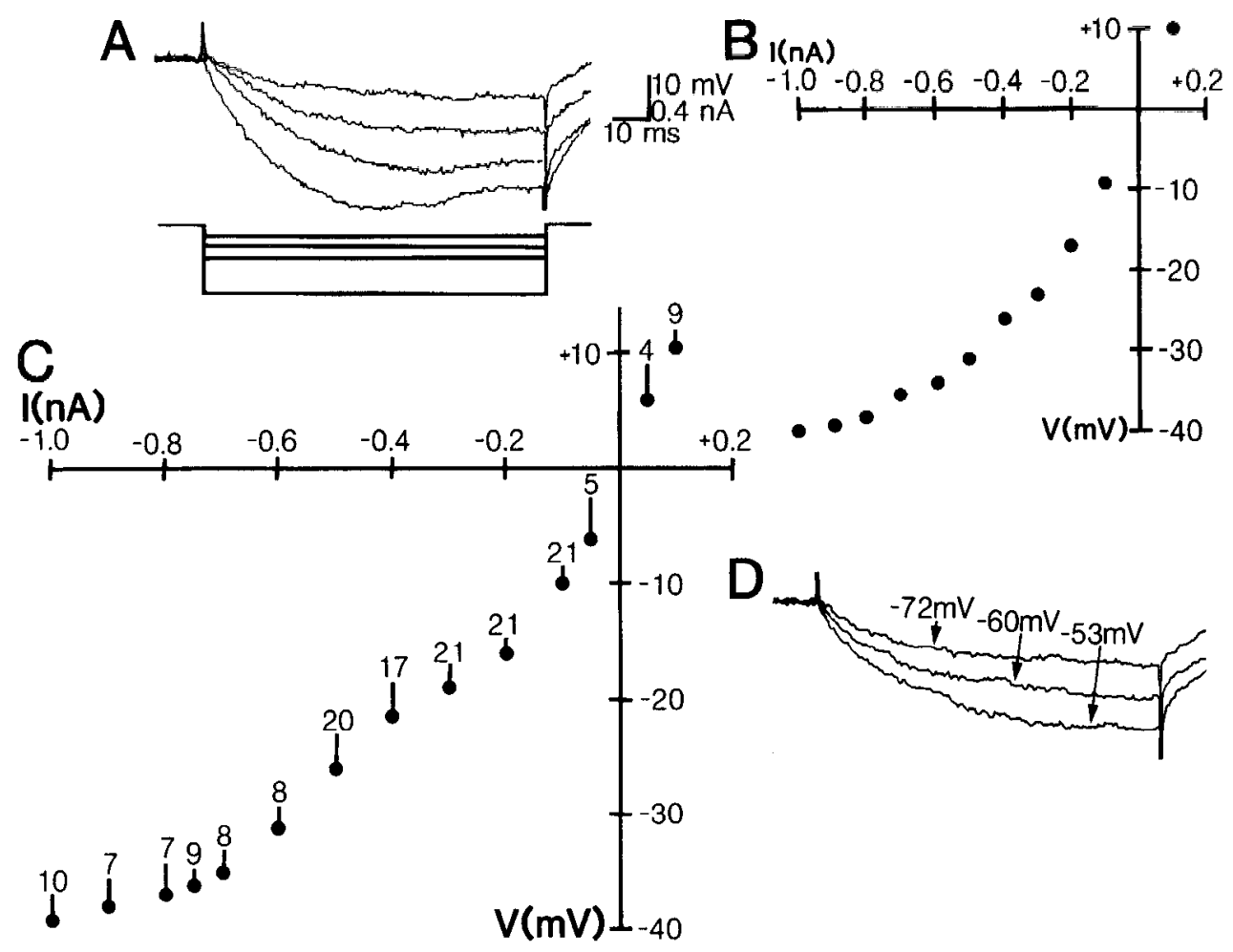

Since our data suggested that mossy cells were located in layer 2 , cells were impaled in that layer. Impalements werc restrictcd to the area of layer 2 closest to the upper blade of the dentate gyrus, since our Nissl-stained sections showed that the layers were less distinct in the area of the hilus closer to the lower blade (Fig. 1 $A$ ). By selecting this area for study, we were also able to minimize the likelihood of impaling pyramidal cells located in the center of the hilus or interneurons lying subjacent to the granule cell layer.

\section{Labeling of mossy cells with Lucifer yellow}

Figure $2, B-F$, shows that the morphological features characteristic of Golgi-stained mossy cells (Fig. 2A) were evident in Lucifer yellow-filled cells. Thorny excrescences were easily identified on the proximal dendrites of these cells (Fig. $2 B$ ). These excrescences were not found on cell bodies, as was the case with our Golgi-impregnated mossy cells (Fig. 2A). Figure 2, $C, D$ illustrates the typical dendritic branching patterns of mossy cells filled with Lucifer yellow. These 2 cells had 3 or 4 large primary dendrites; the dendrites consisted primarily of long segments that branched at acute angles. The dendritic tree was extensive, covering the region from one end of the hilus to the other. However, dendrites rarely passed into the granule cell layer, and some actually appeared to branch in order to avoid doing so.
All of the mossy cells that were stained with Lucifer yellow possessed an axon that originated on the side of the cell closest to the center of the hilus, often starting from a primary dendrite. The cell shown in Figure $2 E$ is an example of a neuron with such an axon, with numerous collaterals that extended towards the center of the hilus and the upper blade of the dentate granule cell layer. Most stained cells were adequately filled with Lucifer yellow to permit visualization of axon collaterals that passed into the dentate granule cell layer, into stratum moleculare, and/ or into stratum oriens of area CA3. Also, as shown in Figure $2 F$, the initial segment of some axons appeared to have spines.

\section{Physiological properties of mossy cells}

Of 57 cells from which successful recordings were made, 21 cells fulfilled the morphological criteria used to identify mossy cells, as well as the electrophysiological criteria for "healthy" neurons. Of the other cells, 28 were physiologically "healthy," but were excluded from the study because they were not stained adequately for unequivocal morphological identification. Five cells were excluded because more than one cell appeared to be stained following intracellular injection of Lucifer yellow into a hilar cell. These cells deserve comment, however, since all had physiological properties indistinguishable from those of the 21 wellstained mossy cells. Clearly, in our recordings, the majority of

Table 1. Membrane properties of mossy cells

\begin{tabular}{llllllc} 
& $\begin{array}{l}\text { RMP } \\
(\mathrm{mV})\end{array}$ & $\begin{array}{l}\text { AP amp. } \\
(\mathrm{mV})\end{array}$ & $\begin{array}{l}\text { AP dur. } \\
(\mathrm{msec})\end{array}$ & $\begin{array}{l}\text { Half-width } \\
(\mathrm{msec})\end{array}$ & $\begin{array}{l}\text { Rin } \\
(\mathrm{M} \Omega)\end{array}$ & $\begin{array}{l}\text { Time } \\
\text { constant } \\
(\mathrm{msec})\end{array}$ \\
\hline $\bar{X}$ & -64.6 & 78.6 & 2.20 & 0.271 & 97.4 & 24.2 \\
SEM & 1.4 & 2.5 & 0.13 & 0.010 & 0.99 & 2.0 \\
Range & $55.5-76.0$ & $65.0-103.0$ & $1.6-3.4$ & $0.2-0.4$ & $50.0-174.0$ & $11.7-34.7$ \\
\hline
\end{tabular}




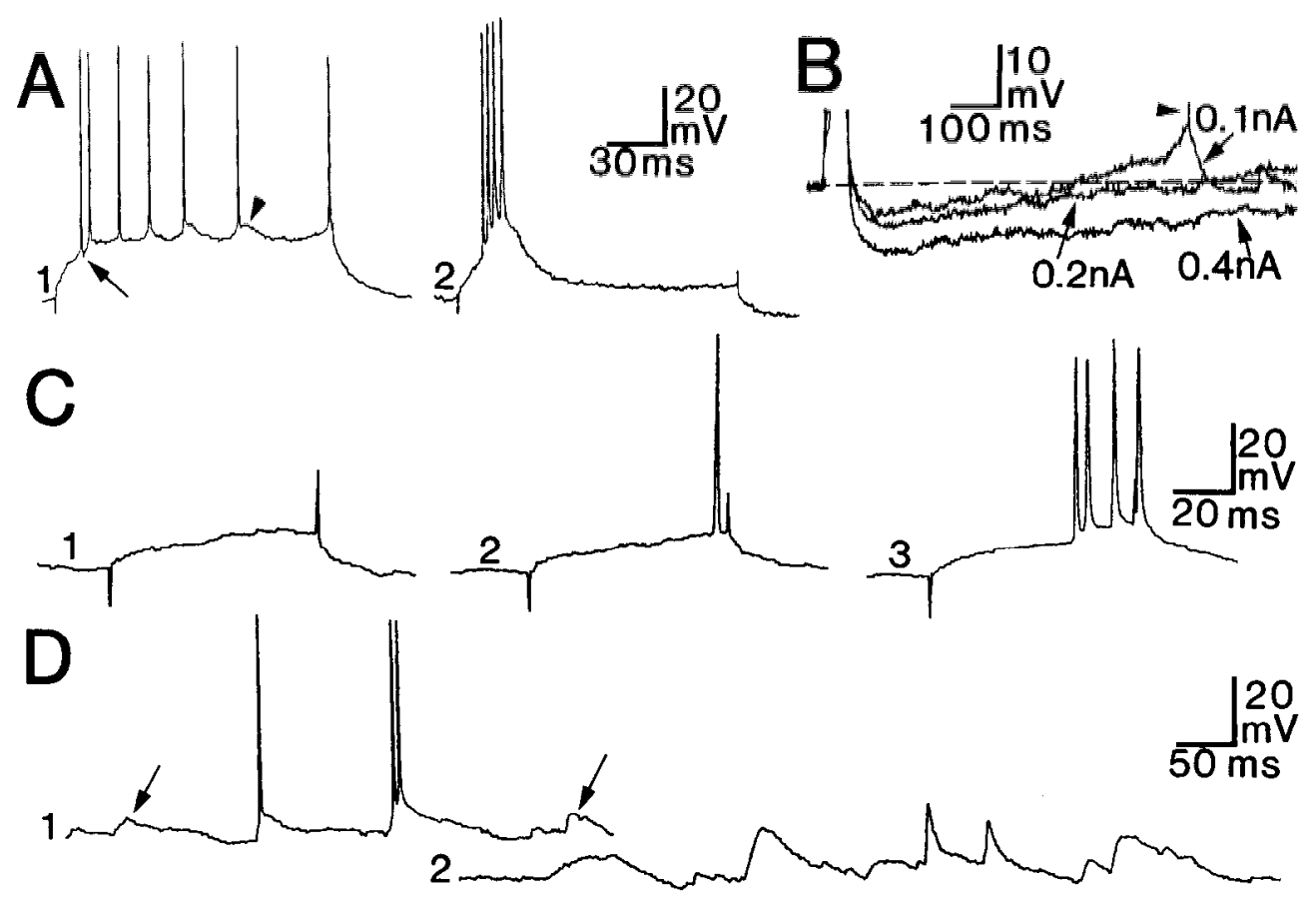

Figure 4. Responses of mossy cells to depolarizing current pulses. $A$, Responses to a $0.3 \mathrm{nA}, 300$ msec depolarizing current pulse in 2 different mossy cells. The cell in 1 is illustrated in Figure $2 D$. The arrow points to an AHP following the first AP. The arrowhead points to a DAP following an AP later in the train. Calibration applies to $l$ and $2 . B$, Burst AHPs following $0.1,0.2$, and $0.4 \mathrm{nA}, 100$ msec depolarizing current pulses. The following number of APs fired in response to the current pulses: $0.1 \mathrm{nA}, 2 \mathrm{APs} ; 0.2 \mathrm{nA}, 3 \mathrm{APs} ; 0.4 \mathrm{nA}, 5$ APs. The arrowhead marks a spontaneous AP that is truncated. RMP, $-64 \mathrm{mV}$. APs were clipped. $C$. Three responses to a $0.1 \mathrm{nA}, 100 \mathrm{msec}$ depolarizing current pulse that were triggered in succession, at least $1 \mathrm{~min}$ apart. In the last trace a spontaneous AP followed the 3 APs elicited during the current pulse. Records are from the cell shown in Figure $2 C$. RMP, $-65 \mathrm{mV}$. D, Spontaneous activity recorded from the same cell as in $C$. 1 , At RMP, spontaneous EPSPs (arrows) were small and single or double APs fired spontaneously. 2, When the cell was hyperpolarized, spontaneous EPSPs increased in amplitude and there were no spontaneous APs.

cells studied in the area of the hilus had common physiological properties.

The 3 remaining cells were physiologically "healthy," and 2 were stained. These cells were similar physiologically to the hippocampal interneurons of area CAl (Schwartzkroin and Mathers, 1978; Knowles and Schwartzkroin, 1981; Lacaille et al., 1987). The dendrites of the stained cells were aspiny or beaded, typical of hippocampal interneurons (and quite different from mossy cclls).

Intrinsic properties of mossy cells. The membrane properties of mossy cells are shown in Table 1. Mean RMP $( \pm$ SEM) was $-64.6 \pm 1.4 \mathrm{mV}$ and mean AP amplitude was $78.6 \pm 2.5 \mathrm{mV}$. The response of mossy cells to hyperpolarizing current pulses revealed their long time constant $(24.2 \pm 2.0 \mathrm{msec})$ and high $R_{\text {in }}(97.4 \pm 0.99 \mathrm{M} \Omega)$. Figure $3 A$ illustrates the response of the cell shown in Figure $2 B$ to a series of hyperpolarizing current pulses. An apparent decrease in $R_{\mathrm{in}}$ occurred when successively larger current pulses were delivered at RMP. This rectification is illustrated in the traces in Figure $3 A$ and in the I-V curve in Figure $3 B$. Note the "sag" in the response to the largest current pulse in Figure $3 A$, a feature that also indicates rectification (Halliwell and Adams, 1982). Rectification was present in all mossy cells; Figure $3 C$ shows an averaged I-V curve based on data from all cells. Mossy cells also demonstrated rectification when the cell membrane potential was manipulated and responses to hyperpolarizing pulses were tested (Fig. $3 D$ ); responses to identical hyperpolarizing pulses were greater when the cell was depolarized and smaller when the cell was hyperpolarized (Hotson et al., 1979).
The AP had a sharp rise, reflected in the brief half-width $(0.271 \pm 0.01 \mathrm{msec})$, but a slow decay, as evidenced in the long total AP duration ( $2.20 \pm 0.13 \mathrm{msec}$; Table 1). Afterpotentials following single APs were variable. When a small-amplitude depolarizing pulse was used to elicit a single spike, there was no afterpotential or a depolarizing afterpotential (DAP) in 13 cells; a small AHP followed single APs in 8 cells $(2.5 \pm 0.49$ $\mathrm{mV}, 10.2 \pm 2.3 \mathrm{msec}$ ). However, in these latter 8 cells, when more than one AP was elicited by a large depolarizing current pulse, subsequent APs were not followed by AHPs; APs late in the train were actually followed by DAPs (Fig. $4 A$ ). The change in afterpotential may reflect a frequency and/or voltage dependence of the current(s) underlying the AHP.

Large depolarizing pulses elicited trains or bursts of APs. Trains of APs demonstrated marked accommodation, and bursts were also followed by a decrease or silencing of activity (Fig. $4 A$ ). Both types of current-induced discharge were followed by large-burst AHPs (for a $0.5 \mathrm{nA}, 100 \mathrm{msec}$ pulse, mean amplitude $\pm \mathrm{SEM}=6.10 \pm 0.77 \mathrm{mV}$; mean duration $=2.14 \pm 0.39 \mathrm{sec}$ ). Burst AHPs increased in amplitude with (1) increased current (Fig. $4 B$ ), (2) increased numbers of APs elicited (Fig. $4 B$ ), and (3) depolarization of the cell by tonic current injection.

A typical feature of the responses of mossy cells to depolarizing pulses was their variability from pulse to pulse (Fig. $4 \mathrm{C}$ ). In 19 of 21 cells, a small, fixed-amplitude current pulse elicited a variable number of APs. This variability could not be attributed to effects of long-lasting burst AHPs, since the variability persisted even when interpulse interval was increased far beyond the burst AHP duration. A more likely explanation is that the 
Figure 5. Responses of a mossy cell to stimulation of different areas of the hippocampus. Examples of responses at threshold are in the left column and subthreshold responses are shown in the right column. Responses elicited by stimulation of site 1 : antidromic AP followed by a DAP. Sites 2-4: shortlatency orthodromic responses. Sites 5 and 6: long-latency orthodromic responses. To facilitate comparison of latencies of APs evoked by stimulation of site 1,3 , or 5 , dashed lines were drawn through the peaks of APs. Inset, A schematic diagram of the hippocampus and the sites of stimulation. Open circles indicate where the poles of the bipolar stimulating electrode were placed on the slice. Axon collaterals of this Lucifer yellow-filled cell were not observed in the areas of the slice where stimulating electrodes were placed. Stimulation occurred at the dots underneath the traces. All responses were recorded from the same cell, which is shown in Figure $2 E$. RMP, $-60 \mathrm{mV}$. Note that traces 1,3 , and 5 have a different time calibration than that of traces 2,4 , and 6 .

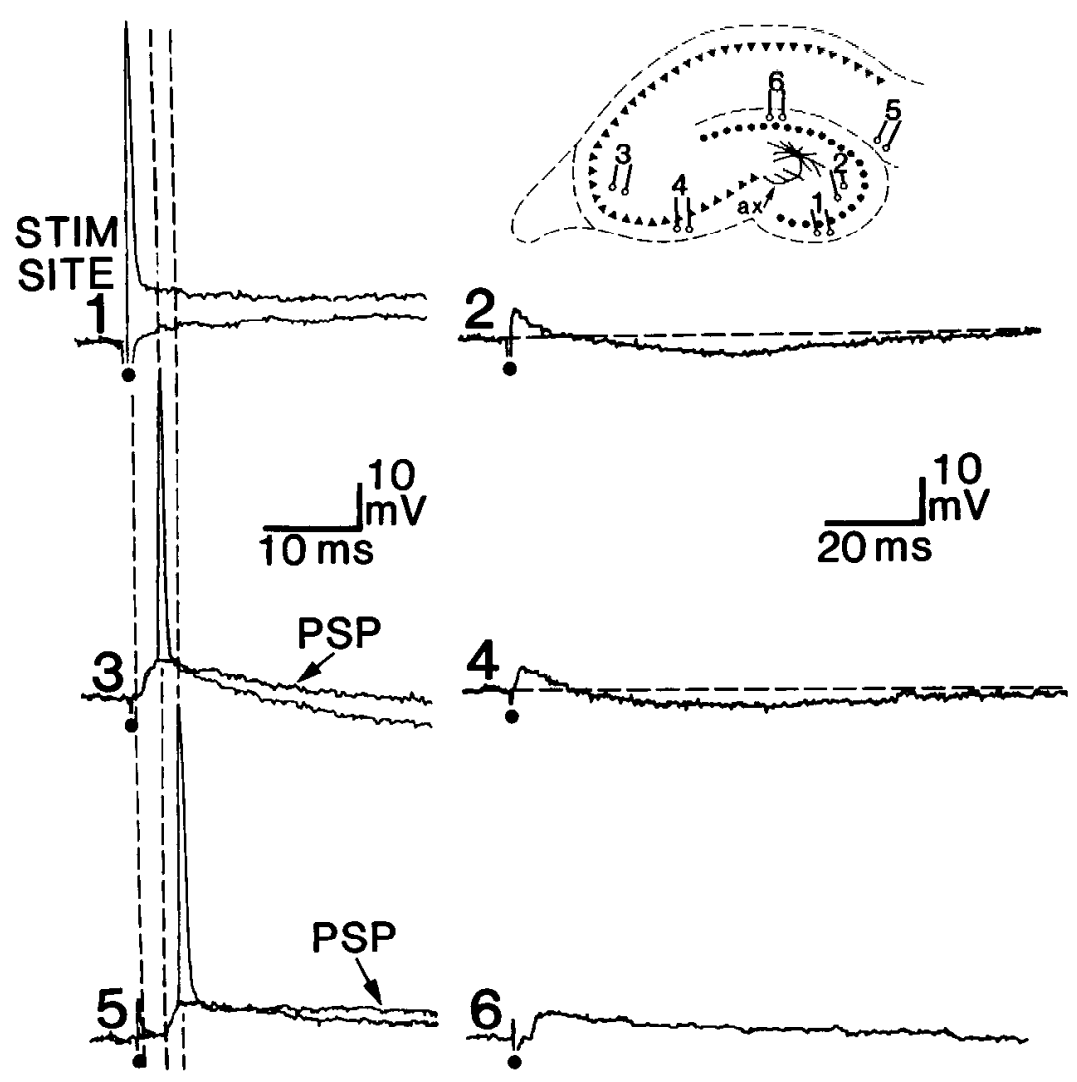

spontaneous synaptic activity present in these cells may have affected the response to successive current pulses. In support of this hypothesis, we found that cells with less spontaneous aclivily were more consistent in their response to current injection than were cells with a high level of baseline spontaneous activity.

The frequency and amplitude of the spontaneous activity were striking (Fig. 4D). Most of the activity took the form of spontaneous depolarizing potentials, although some cells fired spontaneous APs or bursts. This activity did not appear to reflect tissue hyperexcitability, since granule cells and area CA1 hippocampal pyramidal cells impaled in the same slice were not spontaneously active. The spontaneous depolarizing potentials were probably EPSPs; APs often fired at the peak of the depolarizations (Fig. 4D, 1) and PSPs increased in amplitude when the cell was hyperpolarized (Fig. $4 D, 2$ ). They were unlikely to be spontaneous, chloride-dependent IPSPs (which occur elsewhere in the hippocampus; see Alger and Nicoll, 1980), since these spontaneous potentials were still depolarizing in cells that were impaled with electrodes filled with Lucifer yellow dissolved in $\mathrm{Li}_{2} \mathrm{SO}_{4}$ rather than $\mathrm{LiCl}(n=3)$.

Synaptic responses. Every area that was stimulated elicited a response in the 11 cells tested. The following areas were examined: the perforant path (tested in 4 cells), stratum moleculare ( 10 cells), stratum oriens ( 2 cells), stratum lucidum $(1$ cell) or stratum pyramidale ( 5 cells) of area CA3, or the fimbria ( 4 cells) (Fig. 5). These cells could even be driven from as far as the stratum pyramidale of area CAl (Fig. 6) without using higher stimulus strengths than were used to elicit other responses from other stimulus sites. In the one cell in which every stimulus site was tested, responses were elicited from each site.

Regardless of the stimulus site, the most often encountered subthreshold response consisted of a monophasic depolarization (mean amplitude \pm SEM of the depolarization elicited at threshold $=7.4 \pm 2.0 \mathrm{mV}$; mean duration $=80.9 \pm 3.4 \mathrm{msec}$ ). Presumably these potentials were EPSPs since (1) they were graded in amplitudc, (2) APs were triggered at their peaks, and (3) they decreased in amplitude as the membrane potential was depolarized, and increased in amplitude as the membrane potential was hyperpolarized.

In 2 cells, depolarizing potentials with more than one phase were elicited (Figs. 6, 7). These responses were observed only following stimulation of stratum moleculare. Monophasic depolarization were elicited in these cells when other areas of the slice were stimulated.

In 3 cells, depolarizations were evoked by stimulation of some areas of the slice, whereas depolarizations followed by hyperpolarizations were elicited by stimulating other areas, such as area CA3, area CA1, the fimbria, or the hilus (Figs. 5, 6). Both the depolarization and hyperpolarization increased in amplitude as stimulus intensity was raised. Similar stimulus strengths to those used to elicit purely depolarizing responses were used to evoke depolarizations followed by hyperpolarizations.

Hyperpolarizations never preceded depolarizations. These hyperpolarizations were small at RMP (mean amplitude of the hyperpolarization at threshold $=2.5 \pm 1.5 \mathrm{mV}$, mean duration $=120 \pm 34 \mathrm{msec}$ ), but increased in amplitude if the cell was depolarized with current injection. There were no apparent morphological characteristics that could be correlated with the type of synaptic responses that could be elicited.

There were very few differences in the amplitude and duration of depolarizations, or depolarizations and hyperpolarizations, elicited by stimulation at different sites, but there were differences in latency. Although the distances from the hilus varied extensively among different stimulus sites, the synaptic latencies 

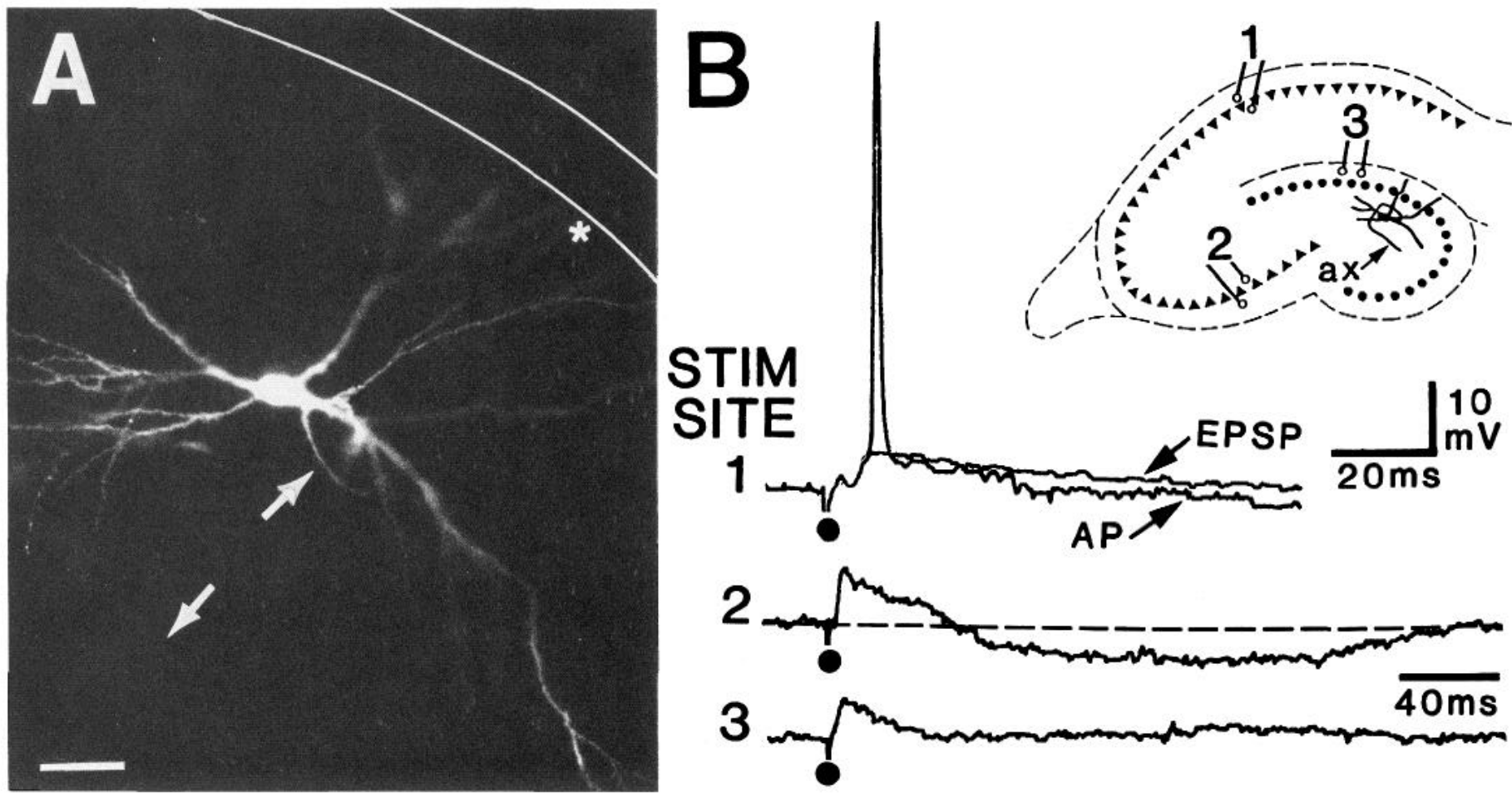

Figure 6. Mossy cell responses to stimulation. A, Photograph of the cell from which recordings were taken. A high-power micrograph of this cell is shown in Figure $2 F$. White lines mark the borders of the granule cell layer. The arrows point to the axon. The dendrite at the asterisk bends sharply away from the granule cell layer. RMP, $-65 \mathrm{mV}$. Calibration, $50 \mu \mathrm{m}$. B, Inset, Diagram of the slice, indicating where stimulating electrodes were placed. 1, Stimulation (at the dot) of stratum pyramidale of area CA1 elicited an AP or EPSP at threshold. 2, Stimulation of stratum pyramidale of area CA3 elicited a biphasic depolarization followed by an IPSP. Dashed line indicates the RMP. 3, Stimulation of stratum moleculare evoked only an EPSP. APs could also be evoked by stimulating sites 2 and 3 at higher intensities.

suggested 2 categories: stimulation of any layer of area CA3 or of the hilus elicited responses of relatively short latency (mean $\pm \mathrm{SEM}=2.5 \pm 0.6 \mathrm{msec}$, range $=1.6-3.1 \mathrm{msec}$ ), whereas stimulation of perforant path, stratum moleculare of the dentate, the fimbria, or area CA1 resulted in responses with longer latencies (mean $=6.0 \pm 0.4 \mathrm{msec}$, range $=4.5-7.3 \mathrm{msec}$; Fig. 5 ). The range of synaptic latencies for each site was as follows: the hilus, 1.6-2.6 msec; area CA3, 1.8-3.1 msec; perforant path, 5.1-7.0 msec; stratum moleculare of the dentate, $4.5-7.3 \mathrm{msec}$; the fimbria, 4.6-6.5 msec; area CA1, 4.5-5.5 msec.

Threshold stimulation elicited one orthodromic AP in 9 of 11 cells that fired on the peak of a depolarization (Fig. 5). In the 2 remaining cells, more than one AP fired at threshold (Fig. $7 A$ ). In these cells the threshold response was quite variable. PSP amplitude and duration varied from stimulus to stimulus and the latency and number of APs also varied. In 8 of the 11 cells, single or multiple APs were followed by long-lasting AHPs (Figs. 6, 7) that increased in amplitude with depolarization.

Suprathreshold stimulation (up to 3 times threshold stimulus strength) evoked one AP in 7 cells, and multiple APs in the 4 other cells. The multiple APs occurred either as a pair of APs on an underlying PSP (Fig. $7 B$ ) or as a burst similar to the burst shown in Figure $7 A$.

Antidromic potentials were elicited in only 3 cells. These responses were likely to be a result of stimulation of a segment of the axon, since they occurred when the area of the slice stimulated (1) was more than $500 \mu \mathrm{m}$ from the intracellular electrode, and (2) was known to contain the axon of mossy cells: the hilus, stratum moleculare of the dentate, or stratum oriens

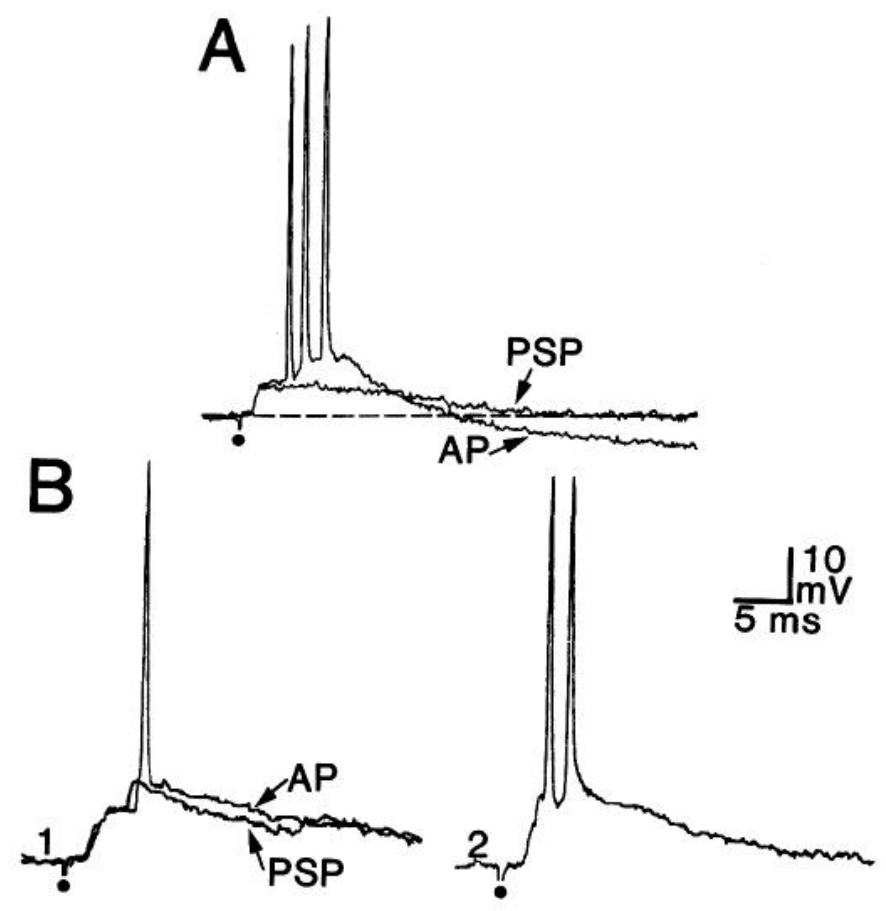

Figure 7. Stimulation of mossy cells can evoke more than one AP. A, Response of a mossy cell to stimulation of stratum moleculare at threshold. Dashed line indicates RMP. Stimulation occurred at the dots. RMP, $-70 \mathrm{mV}$. B, Response of the cell shown in Figure $2 C$ to threshold stimulation $(I)$ and to stimulation at twice threshold stimulus intensity (2) of stratum moleculare. 
of area CA3 (Amaral, 1978; Ribak et al., 1985). In these 3 cells, stimulation at other sites was able to evoke orthodromic responses using stimulus intensities similar to those used to elicit the antidromic APs (Fig. 5). In a reconstruction of one of these Lucifer yellow-filled cells, the axon was evident in the area of stimulation.

\section{Discussion}

\section{Morphology}

Twenty-one cells of the guinea pig dentate hilus were morphologically identified as mossy cells following intracellular injection of Lucifer yellow. The location of their cell bodies, numerous thorny excrescences, and characteristic dendritic and axonal branching patterns distinguished them from other cells in the hilar region. For example, the basket cells subjacent to the granule cell layer (1) do not have thorny excrescences, (2) have a pyramidal-shaped soma, (3) have an axon that arborizes in a basket plexus around granule cell somata and, (4) are located within $100 \mu \mathrm{m}$ of the granule cell layer (Amaral, 1978; Ribak and Seress, 1983), not an area where mossy cells were impaled.

The one characteristic not found in the 21 cells that we examined that has been described as a characteristic of mossy cells was the presence of numerous thorny excrescences on the cell body (Amaral, 1978; Ribak et al., 1985). Since somatic thorny excrescences were also absent from mossy cells that we identified using the Golgi method, it is doubtful that the lack of somatic thorns is an artifact of fluorescence staining. It may reflect a species difference between guinea pig (our results) and rat (Amaral, 1978; Ribak et al., 1985).

\section{Physiology}

All cells that were morphologically identified as mossy cells displayed similar physiological characteristics, making them a homogeneous cell type on both morphological and physiological grounds.

Mossy cclls wcre similar in many of their physiological properties to the pyramidal cells of area CA3. For example, the RMP, AP amplitude and waveform, and time constant of mossy cells were similar to those of area CA3 pyramidal cells (Brown et al., 1981; Wong and Prince, 1981; Johnston, 1981; Masukawa et al., 1982; Turner and Schwartzkroin, 1983). Like pyramidal cells, mossy cells were spontaneously active, and were able to fire APs in accommodating trains or bursts (Wong and Prince, 1981; Masukawa et al., 1982). Afterpotentials were also similar, with little afterpotential or a DAP following a single AP, but a pronounced, long-lasting burst AHP after a series of APs (Wong and Prince, 1981). As is the case for pyramidal cells, rectification was present in mossy cells whether the cell was depolarized or hyperpolarized (Purpura et al., 1968; Hotson et al., 1979; Halliwell and Adams, 1982). However, mossy cells were by no means identical to pyramidal cells. The $R_{\text {in }}$, AP duration, and degree of spontaneous activity of mossy cells were greater than those of CA3 pyramidal cells. The large IPSPs typical of pyramidal cells (Misgeld et al., 1979; Masukawa et al., 1982) were not evident in mossy cells.

Mossy cells were easily distinguished physiologically from other types of cells, such as granule cells. The inability of granule cells to burst and the lack of spontaneous activity (Fricke and Prince, 1984) are in sharp contrast to mossy cells. Mossy cells also differ markedly from the interneurons that have been studied in the hippocampus, either in area CA1 (Schwartzkroin and Mathers, 1978; Knowles and Schwartzkroin, 1981; Lacaille et al., 1987) or located just below the granule cell layer in the fascia dentata (Misgeld and Frotscher, 1986). The lack of accommodative properties, the short-duration AP, and the pronounced AHP following single APs are all characteristics of interneurons (Schwartıkroin and Mathers, 1978; Knowles and Schwartzkroin, 1981; Lacaille et al., 1987) and not of mossy cells.

The responses of mossy cells to stimulation were also different from those of other cell types in the area. For example, mossy cells were excited by stimulation from many different areas of the hippocampus. The fact that relatively short latency responses were elicited when different layers of area CA3 were stimulated indicates that a monosynaptic connection to mossy cells was made from area $\mathrm{CA} 3$; this might have been a result of antidromic activation of mossy fibers of dentate granule cells and excitation of mossy cells due to invasion of the axon collaterals of the dentate granule cell mossy fiber axons. Longerlatency responses elicited from other areas suggest that polysynaptic pathways were involved when those sites were stimulated. Long-latency reponses elicited by stimulation of the perforant path or stratum moleculare of the dentate were probably mediated by perforant path activation of dentate granule cells that, in turn, excited mossy cells. Currently it is unclear what connections exist that were responsible for the excitation of mossy cells following stimulation of area CA1, but preliminary data suggest a direct pathway from area CA2 to the hilus (M. Haglund, personal communication).

Another difference between the synaptic responses of mossy cells and those of other cells of the region was the lack of large IPSPs. Stimulation of the perforant path while recording from interneurons situated subjacent to the granule cell layer elicits an IPSP preceding an EPSP (Misgeld and Frotscher, 1986), whereas stimulation of the same pathway elicits only EPSPs in mossy cells. However, we can not exclude the possibility that in the preparation of hippocampal slices some inhibitory inputs to the mossy cells may have been severed, and therefore there may be more inhibitory input to mossy cells than we were able to detcet.

Mossy cells are certainly not the only physiologically identifiable cell type in the hilus. We found at least one other cell type that was easily distinguished from mossy cells. These cells were very similar to interneurons of area CAl (Schwartzkroin and Mathers, 1978; Knowles and Schwartzkroin, 1981; Lacaille et al., 1987). Such interneuron-like cells were rarely encountered, but they may be more numerous than our results suggest, since mossy cells are large and therefore may be easier to impale than the interneuron-like cells.

\section{Significance to hippocampal physiology}

Several aspects of mossy cell morphology and physiology suggest that these cells may be very important to hippocampal physiology. First, they appear to be a target for numerous inputs to the hilus. Anatomical studies have shown that numerous neurotransmitter systems from many areas of the brain project to the hilus (Storm-Mathisen and Blackstad, 1964; Conrad et al., 1974; Moore and Halaris, 1975; Swanson and Hartman, 1975). The extensive mossy cell dendritic tree branches throughout the hilus (Amaral, 1978), and it thus appears to be designed to receive inputs from multiple-fiber systems, and perhaps to integrate them. Our recordings show that mossy cells have long time constants, making them an ideal integrating unit. Second, mossy cells appear to be extremely sensitive to their inputs, which may be due in part to their high $R_{\mathrm{in}}$. We have shown that there is a tremendous amount and variety of spontaneous excitatory activity present in mossy cells, which is likely to be a 
result of tonic release of transmitter onto mossy cells. Further, their activation results primarily in depolarizing responses, with a limited ability to generate IPSPs. Third, the mossy ccll axon projects widely. It branches in the hilus, and sends projections to stratum moleculare of both the ipsilateral and contralateral dentate gyrus (Gottlieb and Cowan, 1973; Swanson et al., 1978, 1981; Laurberg and Sorensen, 1981; Ribak et al., 1985). Finally, although it is unclear whether dye-coupling of Lucifer yellowfilled neurons is artifactual or evidence of functional coupling between neurons (MacVicar and Dudek, 1981, 1982; Knowles et al., 1982), the fact that we did find dye-coupled hilar neurons suggests another manner in which mossy cells activity might influence other cells of the dentate region.

Thus, mossy cells may be a target for receiving and integrating input from numerous systems external to the hippocampus (Storm-Mathisen and Blackstad, 1964; Conrad et al., 1974; Moore and Halaris, 1975; Swanson and Hartman, 1975). By projecting to most areas of the dentate, mossy cells could provide a context within which the dentate granule cells process information from the perforant path (which is the major source of input for granule cells). In light of the role of the dentate gyrus and hippocampus in a variety of behaviors (Seifert, 1983), this contextual information could be extremely important.

\section{References}

Alger, B. E., and R. A. Nicoll (1980) Spontaneous inhibitory postsynaptic potentials in hippocampus: Mechanism for tonic inhibition. Brain Res. 200: 195-200.

Amaral, D. G. (1978) A Golgi study of cell types in the hilar region of the hippocampus in the rat. J. Comp. Neurol. 182: 851-914.

Andersen, P. (1975) The organization of hippocampal neurons and their interconnections. In The Hippocampus: Structure and Development, vol. I, R. L. Isaacson and K. H. Pribram, eds., pp. 155-175, Plenum, New York.

Blackstad, T. W. (1963) Ultrastructural studies on the hippocampal region. Prog. Brain Res. 3: 71-88.

Brown, T. H., R. A. Fricke, and D. H. Perkel (1981) Passive electrical constants in three classes of hippocampal neurons. J. Neurophysiol. 46: 812-827.

Claiborne, B. J., D. G. Amaral, and W. M. Cowan (1986) A light and electron microscopic analysis of the mossy fibers of the rat dentate gyrus. J. Comp. Neurol. 246: 435-458.

Conrad, L. C. A., C. M. Leonard, and D. W. Pfaff (1974) Connections of the median and dorsal raphe nuclei in the rat: An auroradiographic and degeneration study. J. Comp. Neurol. 156: 179-206.

Fricke, R. A., and D. A. Prince (1984) Electrophysiology of dentate gyrus granule cells. J. Neurophysiol. 51: 195-209.

Gottlieb, D. I., and W. M. Cowan (1973) Autoradiographic studies of the commissural and ipsilateral association connections of the hippocampus and dentate gyrus of the rat. I. The commissural connections. J. Comp. Neurol. 149: 393-422.

Halliwell, J. V., and P. R. Adams (1982) Voltage-clamp analysis of muscarinic excitation in hippocampal neurons. Brain Res. 250: 7192.

Haug, F.-M. S. (1973) Heavy metals in the brain. A light microscope study of the rat with Timm's sulphide silver method. Methodological considerations and cytological and regional staining patterns. Adv. Anat. Embryol. Ccll Biol. 45: 1-71.

Hotson, J. R., D. A. Prince, and P. A. Schwartzkroin (1979) Anomalous inward rectification in hippocampal neurons. J. Neurophysiol. 42: 889-895.

Johnston, D. (1981) Passive cable properties of hippocampal CA3 pyramidal neurons. Cell. Mol. Neurobiol. 1: 41-55.

Knowles, W. D., and P. A. Schwartzkroin (1981) Local circuit synaptic interactions in hippocampal brain slices. J. Neurosci. 1: 318-322.

Knowles, W. D., P. G. Funch, and P. A. Schwartzkroin (1982) Electrotonic and dye coupling in hippocampal CA1 pyramidal cells in vitro. Neuroscience $7: 1713-1722$.
Lacaille, J.-C., A. L. Mueller, D. D. Kunkel, and P. A. Schwartzkroin (1987) Local circuit interactions between oriens/alveus interneurons and CA1 pyramidal cells in hippocampal slices: Electrophysiology and morphology. J. Neurosci. 7: 1979-1993.

Laurberg, S., and K. E. Sorensen (1981) Associational and commissural collaterals of neurons in the hippocampal formation (hilus fasciae dentatae and subfield (CA3). Brain Res. 212: 287-300.

Lorente de No, R. (1934) Studies on the structure of the cerebral cortex. II. Continuation of the study on the ammonic system. J. Psychol. Neurol. (Leipzig) 46: 113-117.

MacVicar, B. A., and F. E. Dudek (1981) Electrotonic coupling between pyramidal cells: A direct demonstration in rat hippocampal slices. Science 213: 782-785.

MacVicar, B. A., and F. E. Dudek (1982) Electrotonic coupling between granule cells of rat dentate gyrus: Physiological and anatomical evidence. J. Neurophysiol. 47: 579-592.

Masukawa, L., L. Benardo, and D. A. Prince (1982) Variation in electrophysiological properties of hippocampal neurons in different subfields. Brain Res. 242: 341-344.

Millhouse, O. E. (1981) The Golgi methods. In Neuroanatomical TractTracing Methods, L. Heimer and M. J. Robards, eds., pp. 311-343, Plenum, New York.

Misgeld, U., and M. Frotscher (1986) Postsynaptic GABAergic inhibition of nonpyramidal neurons in the guinea pig hippocampus. Neuroscience 19: 193-206.

Misgeld, U., J. M. Sarvey, and M. R. Klee (1979) Heterosynaptic postactivation potentiation in hippocampal CA3 neurons: Long-term changes of the postsynaptic potentials. Exp. Brain Res. 37: 217-229.

Moore, R. Y., and A. E. Halaris (1975) Hippocampal innervation by serotonin neurons of the midbrain raphe in the rat. J. Comp. Neurol. 164: 171-185.

Purpura, D. P., S. Prelevic, and M. Santini (1968) Hyperpolarizing increase in membrane conductance in hippocampal neurons. Brain Res. 7: 310-312.

Ramón y Cajal, S. (1911) Histologie du Systéme Nerveux de l'Homme et des Vertèbres, Maloine, Paris.

Ribak, C. E., and L. Seress (1983) Five types of basket cell in the hippocampal dentate gyrus. A combined Golgi and electron microscopic study. J. Neurocytol. 12: 577-597.

Ribak, C. E., L. Seress, and D. G. Amaral (1985) The development, ultrastructure and synaptic connections of the mossy cells of the dentate gyrus. J. Neurocytol. 14: 835-857.

Schwartzkroin, P. A. (1975) Characteristics of CAl neurons recorded intracellularly in the hippocampal "in vitro" slice preparation. Brain Res. 85: 423-436.

Schwartzkroin, P. A., and L. H. Mathers (1978) Physiological and morphological identification of a nonpyramidal hippocampal cell type. Brain Res. 157: 1-10.

Schwartzkroin, P. A., and A. L. Mueller (1987) Electrophysiology of hippocampal neurons. In Cerebral Cortex, vol. 6, E. G. Jones and A. Peters, eds., pp. 295-343, Plenum, New York.

Seifert, W. (1983) The Neurobiology of the Hippocampus, Academic, New York.

Sheehan, D. C., and B. B. Hrapchak (1980) Theory and Practice of Histotechnology, Mosby, St. Louis.

Sloviter, R. (1987) Decreased hippocampal inhibition and a selective loss of interneurons in experimental epilepsy. Science 235: 73-76.

Storm-Mathisen, J., and T. W. Blackstad (1964) Cholinesterase in the hippocampal region. Acta Anat. 56: 216-253.

Swanson, L. W., and B. K. Hartman (1975) The central adrenergic system; immunofluorescence study of the location of cell bodies and their efferent connections in the rat utilizing dopamine-beta-hydroxylase as a marker. J. Comp. Neurol. 163: 467-506.

Swanson, L. W., J. M. Wyss, and W. M. Cowan (1978) An autoradiographic study of the organization of intrahippocampal association pathways in the rat. J. Comp. Neurol. 181: 681-716.

Swanson, L. W., P. E. Sawchenko, and W. M. Cowan (1981) Evidence for collateral projections by neurons in Ammon's horn, the dentate gyrus and the subiculum: A multiple retrograde labeling study in the rat. J. Neurosci. 1: 548-559.

Turner, D. A., and P. A. Schwartzkroin (1983) Electrical characteristics of dendrites and dendritic spines in intracellularly stained CA3 and dentate hippocampal neurons. J. Neurosci. 3: 2381-2394.

Wong, R. K. S., and D. A. Prince (1981) Afterpotential generation in hippocampal pyramidal cells. J. Neurophysiol. 45: 86-97. 